\title{
Sea ice dynamics influence halogen deposition to Svalbard
}

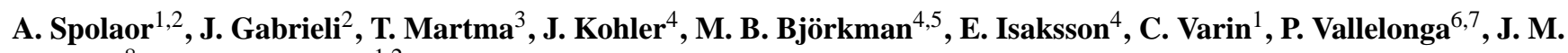 \\ C. Plane ${ }^{8}$, and C. Barbante ${ }^{1,2}$ \\ ${ }^{1}$ Department of Environmental Sciences, Informatics and Statistics, University Ca' Foscari of Venice, Dorsoduro 2137, \\ 30123 Venice, Italy \\ ${ }^{2}$ Institute for the Dynamics of Environmental Processes - CNR, University of Venice, Dorsoduro 2137, 30123 Venice, Italy \\ ${ }^{3}$ Institute of Geology, Tallinn University of Technology, Ehitajate tee 5, 19086 Tallinn, Estonia \\ ${ }^{4}$ Norwegian Polar Institute, Fram Centre, Hjalmar Johansens gt. 14, 9296 Troms $\varnothing$, Norway \\ ${ }^{5}$ Department of Geosciences, University of Oslo, P.O. Box 1047, Blindern, 0316 Oslo, Norway \\ ${ }^{6}$ Centre for Ice and Climate, Niels Bohr Institute, Juliane Maries Vej 30, 2100 Copenhagen, Denmark \\ ${ }^{7}$ Department of Imaging and Applied Physics, Curtin University, Kent St, Bentley WA 6102, Australia \\ ${ }^{8}$ School of Chemistry, University of Leeds, Leeds, LS2 9JT, UK
}

Correspondence to: A. Spolaor (andrea.spolaor@unive.it)

Received: 28 January 2013 - Published in The Cryosphere Discuss.: 8 March 2013

Revised: 20 September 2013 - Accepted: 30 September 2013 - Published: 31 October 2013

\begin{abstract}
Sea ice is an important parameter in the climate system and its changes impact upon the polar albedo and atmospheric and oceanic circulation. Iodine (I) and bromine $(\mathrm{Br})$ have been measured in a shallow firn core drilled at the summit of the Holtedahlfonna glacier (Northwest Spitsbergen, Svalbard). Changing I concentrations can be linked to the March-May maximum sea ice extension. Bromine enrichment, indexed to the $\mathrm{Br} / \mathrm{Na}$ sea water mass ratio, appears to be influenced by changes in the seasonal sea ice area. I is emitted from marine biota and so the retreat of March-May sea ice coincides with enlargement of the open-ocean surface which enhances marine primary production and consequent I emission. The observed $\mathrm{Br}$ enrichment could be explained by greater $\mathrm{Br}$ emissions during the $\mathrm{Br}$ explosions that have been observed to occur mainly above first year sea ice during the early springtime. In this work we present the first comparison between halogens in surface snow and Arctic sea ice extension. Although further investigation is required to characterize potential depositional and post-depositional processes, these preliminary findings suggest that I and $\mathrm{Br}$ can be linked to variability in the spring maximum sea ice extension and seasonal sea ice surface area.
\end{abstract}

\section{Introduction}

Sea ice is an important parameter of the Earth climate system as it affects global albedo and the net radiation balance of the Earth (Francis et al., 2009), as well as oceanic circulation (Holland et al., 2001). Autumn and winter sea ice formation causes an expulsion of salts into oceanic surface water with the result of producing denser surface water with respect to spring and summer surface waters, which are freshened by melting sea ice. Consequently, sea ice production alters surface Arctic Ocean stratification (Warren, 1983). Aagaard and Carmack (1989) proposed that the southward transport of sea ice through the surface circulation of the Arctic Sea could bring sea ice and fresh water to the deep water formation areas of the Labrador Sea and around the Greenland coasts. Additionally, sea ice forms an effective barrier between the atmosphere and the ocean surface, reducing the thermal and chemical exchange between these two compartments. Sea ice is also important for the polar biological community, from microalgae (Pabi et al., 2008) to the great mammals (Durner et al., 2009).

A synthesis of Arctic sea ice reconstructions has found a slight decline starting early in the 20th century (Polyak et al., 2010), with an overall retreat of both the summer and winter sea ice areas since the early 1980s. Recent satellitebased observations of sea ice have greatly improved our 
understanding of sea ice variability, in terms of temporal resolution (from daily to monthly) as well as surface area and thickness (Stern et al., 1995; Serreze et al., 2003; Parkinson and Comiso, 2013). In particular, satellite measurements have definitively demonstrated the rapid increase in sea ice loss during the last decades and particularly during the last $10 \mathrm{yr}$ (Stroeve et al., 2007). In this period the four lowest summer sea ice minima of the last $30 \mathrm{yr}$ have been recorded (data from Arctic Sea-Ice Monitor - IJIS at the www.ijis.iarc.uaf.edu) with the lowest sea ice extension recorded on 16th September 2012, with a surface area of 3.41 million $\mathrm{km}^{2}$ (7.2 million $\mathrm{km}^{2}$ during the early satellite period). The previous minimum was in 2007 with an extension of 4.17 million $\mathrm{km}^{2}$ (data from National Snow and Ice Data Center, nsidc.org). Different model scenarios have been proposed to predict Arctic sea ice decline (Wang and Overland, 2012), however the most recent measurements have highlighted that the present-sea-ice decline exceeds all predictions (Stroeve et al., 2007). Sea ice is one of the most sensitive components of the Earth climate system (Kinnard et al., 2011), with models potentially underestimating all of the different aspects that contribute to sea ice variability (Rampal et al., 2011).

Accurate reconstruction of sea ice variability before the satellite era is important for understanding interactions between sea ice extension and both the forcing and effects of climatic changes. These results are also important for model calibration. Many different approaches have been proposed to reconstruct sea ice variability. Marine sediment cores are widely used due to their capability to record the source of sediment and thus the pathways of Arctic and sub-Arctic oceanic circulation (Darby, 2003). The occurrence of floating ice could be revealed by the presence of ice-rafted debris (Lisitzin, 2002), while sea ice-related palaeo-productivity can be inferred from the sedimented remains of microscopic organisms and other biomarkers (Cronin et al., 2008). Recently, the determination of highly branched isoprenoids $\left(\mathrm{IP}_{25}\right)$ in specific sea ice diatoms have been proposed to describe the past sea ice variability (Vare et al., 2009; Fahl and Stein, 2012). Coastal records also help to understand the past dynamics of sea ice, producing a clear signal both in coastal sediment and landforms (Polyak et al., 2010). In addition integration of various palaeoclimate archives allows a broad reconstruction of past sea ice variability in the Arctic (Kinnard et al., 2011).

A weakness of the available reconstructions of palaeo-sea ice dynamics is that they are characterized by poor temporal resolution. Many atmospheric conditions are recorded in ice core proxies, such as dust deposition, temperature, solar radiation and atmospheric gas concentration (Wolff et al., 2010) and so they are employed extensively for reconstructing past climates (Petit et al., 1999). The absence of reliable and specific proxies has limited their application to reconstructions of sea ice dynamics. Methanesulfonic acid (MSA) has been used to reconstruct sea ice variability over the last few centuries at Law Dome in Antarctica (Curran et al., 2003) and from the Lomonosovfonna ice core from Svalbard (Isaksson et al., 2005). Although a positive correlation was found between MSA and sea ice for the Law Dome site, the Lomonosovfonna MSA record showed a negative correlation between sea ice extent and MSA concentration. It has been proposed that the reduced ice cover in the Barents Sea allowed a greater area for primary production as well as warmer water temperatures, thereby promoting DMS production (O'Dwyer et al., 2000). MSA is susceptible to post-depositional mobility and loss which renders it unsuitable for millennial-scale sea ice reconstruction (Smith et al., 2004). Sea salt sodium (ss-Na) has also been discussed to estimate past sea ice variations (Wolff et al., 2006). The sea ice surface is salt enriched mainly because of the salt expelled in high salinity frost flowers and brine (Rankin et al., 2000) which can be lofted into the atmosphere and deposited on surface snow. However, a recent paper suggests that frost flowers are very stable in the presence of wind and no aerosol emission was observed in laboratory studies (Roscoe et al., 2011). Despite the suggested links between sodium and sea ice (Wolff et al., 2006), the contribution of open-ocean sea spray and wind transport, as well as the role of the frost flower-brine production and sodium dust deposition, must be taken into account (Petit et al., 1999). There has been much recent progress in satellite-based measurements of trace gases in the atmosphere (Saiz-Lopez et al., 2007). In particular, satellite images show that high levels of $\mathrm{BrO}$ and IO in the Antarctic atmosphere are located above seasonal or first-year sea ice (Schönhardt et al., 2012; Kaleschke et al., 2004). The increase of $\mathrm{BrO}$ concentration during the austral spring is likely due to the reaction of bromine with ozone which is one of the main mechanisms of ozone depletion events (ODEs) (Fan and Jacob, 1992) triggered by the injection of gas-phase bromine into the polar atmosphere during bromine explosions (Simpson et al., 2007). Simpson et al. (2007) and Kaleschke et al. (2004) revealed that the occurrence of bromine explosions are linked with the presence of first-year sea ice and in particular with the fresh snow above first year sea ice (Pratt et al., 2013). These observations are also detected above Arctic sea ice where the atmospheric content of $\mathrm{BrO}$ is enhanced in spring time (Sihler et al., 2012).

Increased concentrations of iodine monoxide (IO), observed above Antarctic first year sea ice in the austral spring, have been related to production from algae growing under sea ice (Atkinson et al., 2012; Saiz-Lopez and Boxe, 2008). However, in the Arctic region, satellite measurements of IO do not show particularly high tropospheric concentrations during spring time (Schönhardt et al., 2008). On the other hand, recent differential optical absorption spectroscopy (DOAS) boundary layer IO measurements suggest an active iodine chemistry during March-May period in the near-surface atmospheric layer $(<100 \mathrm{~m})$ associated with the formation of open leads or polynyas (Mahajan et al., 2010). 
In this work we present iodine and bromine concentrations in a shallow firn core recovered in April 2012 from the Holtedahlfonna glacier in Svalbard. The core chronology, achieved by combined annual layer counting (ALC) and glaciological mass balance calculations, reveals that this record covers the last decade of snow deposition. Iodine and bromine were measured by inductively coupled plasma sector field mass spectrometry (ICP-SFMS) under ultra-clean conditions. The results suggest that the variations in iodine concentration could be associated with changes in MarchMay sea ice extension, while bromine enrichment (relative to the $\mathrm{Br} / \mathrm{Na}$ sea water mass ratio) is related to the variation of seasonal sea ice surface area.

\section{Samples and methods}

\subsection{Firn and snow sampling}

In April 2012, an $11 \mathrm{~m}$ long firn core was recovered from the summit of the Holtedahlfonna glacier, Spitsbergen, Svalbard $\left(79^{\circ} 09^{\prime} \mathrm{N}, 13^{\circ} 23^{\prime} \mathrm{E} ; 1150 \mathrm{~m}\right.$. a.s.l.) using a $4^{\prime \prime}$ aluminium auger powered by an electric drill. The sampling location is shown in Fig. 1a. The core was drilled from the bottom of a $2.4 \mathrm{~m}$ snowpit, at the transition between the 2011 firn layer and the seasonal snowpack. The principal physical features of each firn core section (length, layering, dust horizons, ice lenses, crystallography) were recorded in the field. Stratigraphic snow samples were also collected, by inserting low density polyethylene (LDPE) vials perpendicularly into the snow-pit wall with a spatial resolution of $\sim 5 \mathrm{~cm}$ down to a depth of $2.35 \mathrm{~m}$. Considering that trace element concentrations in high altitude snow and ice samples are extremely low (ranging from $\mathrm{ng} \mathrm{g}^{-1}$ to sub-pg g ${ }^{-1}$ ), the samples were collected using the same stringent anti-contamination procedures developed for collecting snow and firn in Antarctica (Candelone et al., 1994). All sampling tools and LDPE bottles were pre-cleaned with diluted ultra-pure $\mathrm{HNO}_{3}$ (Ultrapure grade, Romil, Cambridge, UK) and then rinsed several times with ultra-pure water (UPW, Purelab Ultra Analytic, Elga Lab Water, High Wycombe, UK). The scientists wore clean-room clothing and polyethylene (PE) gloves during the sampling. First, the surface of the snow-pit wall was removed with a PE scraper to avoid sampling any areas that may have been contaminated during the digging. The mass of each sample was 50 to $90 \mathrm{~g}$, depending on the density of the sampled snow layer. The snowpack stratigraphy was recorded and physical parameters such as temperature, snow density, grain shape and size, and hardness indexes (hand test and Swiss Rammesonde method) were measured. The form of the snow grains and their dimensions were established according to the International Association of Cryospheric Science classification.

\subsection{Sample preparation}

The firn core sections were processed in a class-100 laminar flow hood in the laboratory of the Italian research station in Ny-Ålesund. Core sections were cut to $5 \mathrm{~cm}$ resolution with a commercial hand saw that was carefully cleaned with methanol and UPW before each cutting operation. Processed samples were kept frozen in dark conditions to avoid any photo-activation of the halogens. The firn ice core samples were decontaminated according to a simplified chiselling procedure (Candelone et al., 1994), using a ceramic knife pre-cleaned with UPW. Three different knives were used to chisel away successive layers which may have been contaminated during drilling, handling, transport and storage. The decontaminated firn samples were sealed into UPWrinsed PE bags, melted at room temperature in darkness and then aliquotted into LDPE vials. To evaluate the possibility of contamination due to sample processing, artificial ice cores produced from UPW were handled and prepared in an identical manner to the samples. No external contamination was detected as a consequence of the core processing.

Snow-pit samples were transported directly to Venice, then melted at room temperature under a class 100 laminar flow bench. For halogens analysis $10 \mathrm{~mL}$ of melted water was transferred to $12 \mathrm{~mL}$ acid-cleaned LDPE vials. Other aliquots were taken for determination of stable isotope ratios and concentrations of major and minor ions and trace elements.

\subsection{Analytical methods}

Concentrations of I and $\mathrm{Br}$, as well as other 28 trace elements, were determined by Inductively Coupled Plasma Sector Field Mass Spectrometry (ICP-SFMS; Element2, ThermoFischer, Bremen, Germany) equipped with a cyclonic Peltier-cooled spray chamber (ESI, Omaha, US), following the methods of (Gabrielli et al., 2005). The sample flow was maintained at $0.4 \mathrm{~mL} \mathrm{~min}^{-1}$. Based on the method proposed by $\mathrm{Bu}$ et al. (2003), we developed an analytical procedure for the measurement of total $\mathrm{Br}$ and I in firn/ice samples. Particular attention was paid to maintaining a rigorous cleaning procedure between analyses as the measurement of these elements is sensitive to instrumental memory effects. A $24 \mathrm{~h}$ cleaning cycle was adopted before each analytical session to guarantee a stable background level. The $24 \mathrm{~h}$ cleaning cycle consisted of alternate flushing of ammonia solution $5 \%$ (prepared from TraceSELECT ${ }^{\circledR}$ ammonium hydroxide solution, Sigma Aldrich, MO, US) for $3 \mathrm{~min}$, followed by a UPW rinse lasting $30 \mathrm{~s}$, and a $2 \% \mathrm{HNO}_{3}$ wash (trace metal grade, Romil, Cambridge, UK) for 3 min. Between each analysis a single $\mathrm{NH}_{4} \mathrm{OH}$, UPW, $\mathrm{HNO}_{3}$, UPW cycle was sufficient to ensure that the background value is achieved (difference of $<1 \%$ compared to the initial background level). Iodine and $\mathrm{Br}$ were calibrated by external calibration using standards of 10 to $4000 \mathrm{pg} \mathrm{g}^{-1}$. I and $\mathrm{Br}$ standards were prepared by diluting $1000 \mathrm{mg} \mathrm{L}^{-1}$ stock IC standard solutions 


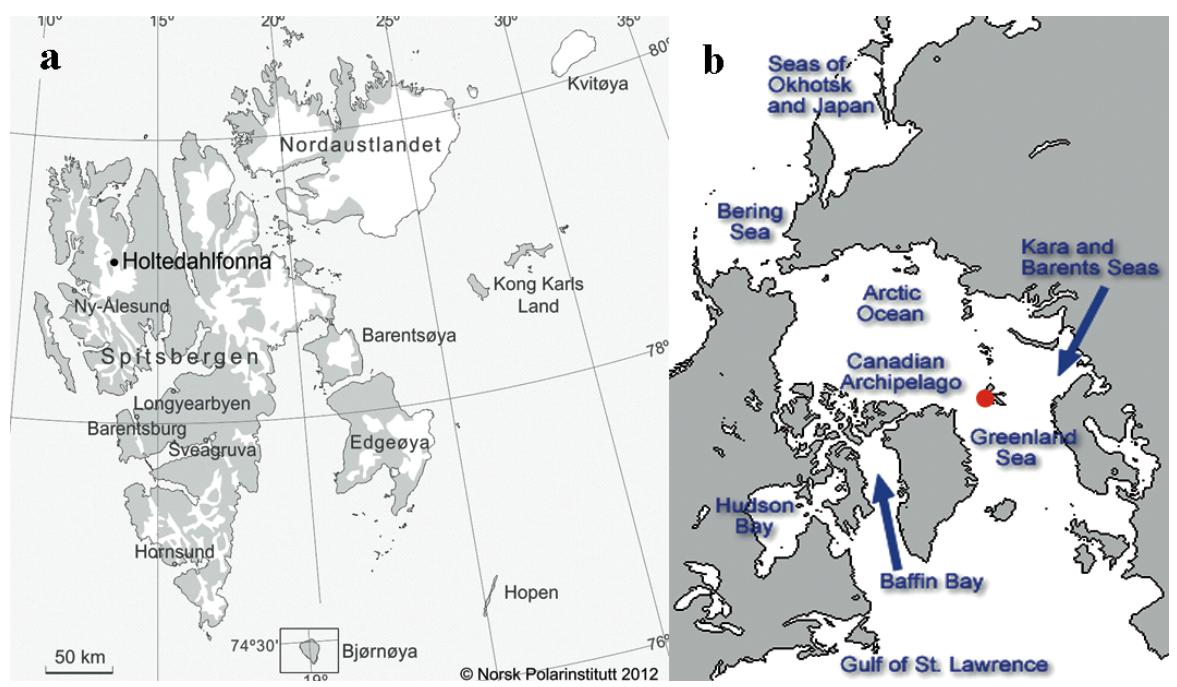

Fig. 1. (a) Map of the drilling site $\left(79^{\circ} 09^{\prime} \mathrm{N}, 13^{\circ} 23^{\prime} \mathrm{E} ; 1150 \mathrm{~m}\right.$ a.s.1.) at Holtedahlfonna glacier at Spitsbergen, Svalbard (courtesy of Norwegian Polar Institute). (b) Descriptive map of the Arctic sea ice regions (from NSIDC) and a red dot indicate the Spitzbergen firn core location.

(TraceCERT ${ }^{\circledR}$ purity grade, Sigma-Aldrich, MO, USA) in UPW. All calibration curves showed correlation coefficients greater than $0.99(\mathrm{~d} f=4, p=0.05)$. Detection limits, calculated as three times the standard deviation of the blank, were 5 and $50 \mathrm{pg} \mathrm{g}^{-1}$ for ${ }^{127} \mathrm{I}$ and ${ }^{79} \mathrm{Br}$, respectively. Reproducibility was evaluated by repeating measurements of selected samples characterized by different concentration values (between $20 \mathrm{pg} \mathrm{g}^{-1}$ and $400 \mathrm{pg} \mathrm{g}^{-1}$ for I and between 400 and $600 \mathrm{pg} \mathrm{g}^{-1}$ for $\mathrm{Br}$ ). The residual standard deviation (RSD) was low for both halogens and ranged between 1-2\% and $2-10 \%$ for $\mathrm{Br}$ and I, respectively.

A Picarro L2120-i Isotopic Liquid Water Analyzer with High Precision Vaporizer A0211 was used to measure $\delta^{18} \mathrm{O}$. The reproducibility of repeated measurements was better then $\pm 0.1 \%$ o. Isotopic compositions measured are reported in the common delta units relative to standard VSMOW.

\subsection{Statistical approach}

We also developed a statistical segmentation of the $\delta^{18} \mathrm{O}$ time series into subseries corresponding to each of the observation years from 2003 to 2011. In order to obtain this segmented series, we first applied a smoothing spline to the $\delta^{18} \mathrm{O}$ time series and interpolated the series onto a regular grid. We then identified the turning points of the smoothed $\delta^{18} \mathrm{O}$ series, with peaks corresponding to summer periods and troughs corresponding to winter periods. Turning-point identification was performed using Kendall information theory (Kendall, 1976) as implemented in the function "turnpoints" of the R (R Core Team, 2011) package "pastecs" (Ibanez et al., 2009). The peaks (summers) identified by this software are denoted in Fig. $2 \mathrm{~d}$ as solid red triangles, while the troughs (winters) are denoted as solid blue inverted triangles. Ac- cordingly, each calendar year corresponds to the period between consecutive blue triangles. For the data corresponding to 2005, the algorithm automatically determined two peaks; however, when combined with Holtedahlfonna mass balance data we attributed summer to the first peak. These invalid turning points are denoted by empty red and blue triangles in Fig. 2d. The segmentation of the $\delta^{18} \mathrm{O}$ time series was used to identify the $\% \mathrm{Br}_{\text {enr }}$ and I data pertaining to the various observation years and hence allowed the calculation of annual average values of $\% \mathrm{Br}_{\mathrm{enr}}$ and $\mathrm{I}$.

The significance of Pearson correlations between the annual averages of $\% \mathrm{Br}_{\text {enr }}$ and seasonal sea ice area, and between iodine fluxes and March-May sea ice extent, was evaluated with the usual Fisher $Z$ transform approach. $P$ values were adjusted for multiple testing using the False Discovery Rate method (Benjamini and Hochberg, 1995). Hereafter, correlation values, $p$ values and adjusted $p$ values for testing the absence of correlation are indicated as $r=x x, p$ value $=x x$, adj. $p=x x$, respectively.

Pearson correlation is based on assumptions of linearity and normality that are difficult to assess with short data series. In order to avoid overinterpretation of the results, Kendall tau rank correlations were also evaluated. Kendall tau provides an alternative measure of association that it is unaffected by linearity and normality assumptions. However, given that only a short data series was available for producing the statistical comparisons in Sects. 3.2 and 3.3, we consider these findings to be preliminary and only indicative.

Air mass back trajectories arriving at $2000 \mathrm{~m}$ a.s.l. were calculated twice a day for the period March-May (20032011) using the Hybrid Single Particle Lagrangian Integrated Trajectory (HYSPLIT) model (Draxler and Hess, 


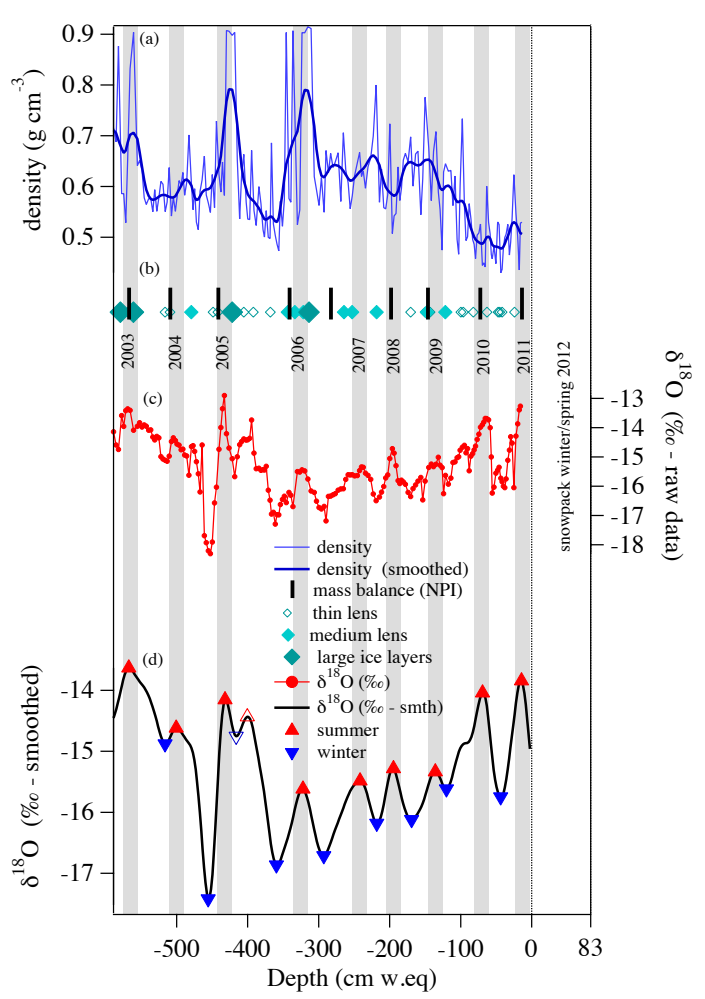

Fig. 2. ${ }^{18} \mathrm{O}$ isotopic ratios (b) and density profiles (a) in the Holtedahlfonna firn core. Vertical black bars (c) indicate mass balance measurements carried out at $1150 \mathrm{~m}$ a.s.l. in the Holtedahlfonna glacier summit, $40 \mathrm{~m}$ west of the drilling site. Diamonds (c) indicate the presence of ice lenses in the core; the increasing size of the diamond represents increasing thickness of the lenses. These are characterized as thin $(<20 \mathrm{~mm})$, medium $(20-100 \mathrm{~mm})$ and large $(>100 \mathrm{~mm})$. These data have been used to construct the core chronology, which covers $10 \mathrm{yr}$ of deposition. Statistical assessment of the smoothed (smth) ${ }^{18} \mathrm{O}$ profile turnpoints (d). Solid red triangles indicate assigned summer peaks and solid blue triangles indicate assigned winter troughs. Empty red and blue triangles indicate spurious assignments of summer peaks and winter troughs. The grey bars indicate summer periods as inferred from the data set.

1998) using NCEP meteorological reanalysis data (Kalnay et al., 1996) and clustered for 3 or 6 days back in time.

\section{Results and discussion}

\subsection{Firn core chronology}

Unlike the majority of the glaciers of Svalbard, the uppermost part of the Holtedahlfonna has a positive mass balance and hence preserves most of its annual snow deposition. Over the eight years, the net mass balance at the top of Holtedahlfonna glacier ( $1150 \mathrm{~m}$ a.s.l.) ranged from 640 to $1100 \mathrm{~mm}$ w.eq. (average $760 \pm 145 \mathrm{~mm}$ w.eq.). The summer accumulation ranged from $-38 \%$ (ablation) to $+4 \%$ (accumulation) of the total, with an average value of $-8 \%$
(Fig. 2b). Some melting and percolation is indicated by the presence of several ice lenses in the core (Fig. 2b); however, it has been proposed that melt events have only a minor influence on the seasonal climatic signal determined from the $\delta^{18} \mathrm{O}$ signal in Svalbard cores (Pohjola et al., 2002). This is also confirmed by our results, where a clear seasonality has been detected (Fig. 2c, d) despite the presence of melt layers. The core has been dated based on the seasonal variations of $\delta^{18} \mathrm{O}$ as well as from annual mass balance calculations obtained from the difference between the winter accumulation and the summer melting. Mass balance estimates have been carried out through the measurement of several ablatometric stakes along the Holtedahlfonna glacier. The uppermost stake is located very close to the drilling site (about $40 \mathrm{~m}$ ) and it provides precise and accurate accumulation data of the surrounding area. For this reason, mass balance measurements at stake 8 are used to support isotopic dating, especially when the $\delta^{18} \mathrm{O}$ shows ambiguities (e.g. 2005 summer season, see Fig. 2). The shallow core and the snowpit cover the period from winter 2003 to spring 2012 (Fig. 2), with less than \pm 1 yr uncertainty in the dating. Many factors can affect the accurate reconstruction of local temperatures based on the Holtedahlfonna $\delta^{18} \mathrm{O}$ profile, hence we only use the $\delta^{18} \mathrm{O}$ profile to evaluate annual deposition cycles.

\subsection{Iodine and March-May sea ice}

Iodine concentrations in Holtedahlfonna glacier samples ranged from below the detection limit $\left(5 \mathrm{pg} \mathrm{g}^{-1}\right)$ to 249 $\mathrm{pg} \mathrm{g}^{-1}$ (depth $68.9 \mathrm{~cm}$ w.eq), with most concentrations less than $118 \mathrm{pg} \mathrm{g}^{-1}$ (Fig. 3). These values were compared to $\mathrm{Na}$ concentrations to ensure that marine salts did not significantly influence the I concentration at Holtedahlfonna glacier. The influence of sea salt deposition was calculated using $\mathrm{Na}$ as a conservative marine salt marker and considering a representative value of the seawater $\mathrm{I} / \mathrm{Na}$ mass ratio of $5.9 \times 10^{-5}$ (Turekian, 1968). On this basis, sea salt I was found to consistently account for less than $2 \%$ of iodine concentrations.

Iodine can be emitted from the ocean in a number of ways. Firstly, via biological production and emission of a variety of organo-iodine compounds (Carpenter, 2003). Although $\mathrm{CH}_{3} \mathrm{I}$ is the major organo-iodine species, it is photolysed relatively slowly in the atmosphere and thus is a less important source of active iodine radicals (I, IO, OIO) in the atmospheric boundary layer than photo-labile species such as $\mathrm{CH}_{2} \mathrm{I}_{2}$ and $\mathrm{CH}_{2} \mathrm{ICl}$ (Carpenter, 2003); secondly, by biological production of $\mathrm{I}_{2}$ from macroalgae, which is important in coastal areas (Saiz-Lopez and Plane, 2004); lastly, the uptake of $\mathrm{O}_{3}$ at the ocean surface and its reaction with iodide $\left(\mathrm{I}^{-}\right)$ions causes the emission of HOI and $I_{2}$ (Carpenter et al., 2013). It has been postulated that algae growing under the sea ice around Antarctica produce $\mathrm{I}_{2}$ which percolates up through the ice and is then emitted to the atmosphere (Saiz-Lopez and Boxe, 2008; Atkinson et al., 2012). This source would account for 


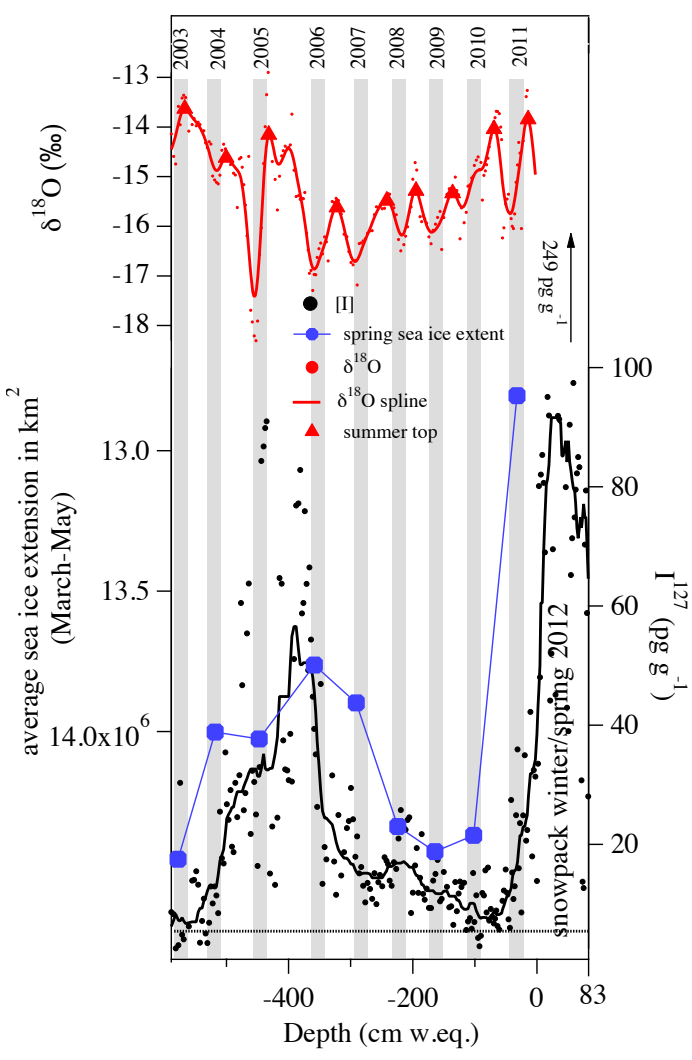

Fig. 3. Iodine concentrations in $\mathrm{pg} \mathrm{g}^{-1}$ (black circles) compared with spring sea ice extent in $\mathrm{km}^{2}$ (blue circles, reverse scale). Increased I concentrations in the firn core can be linked to decreased spring sea ice extension. The ${ }^{18} \mathrm{O}(\%)$ profile is shown in red. The grey bars indicate spring-summer periods. The dotted line indicates the iodine detection limit $\left(5 \mathrm{pg} \mathrm{g}^{-1}\right)$. Sea ice data from NSIDC.

the very high levels of IO radicals which have been observed in the coastal marine boundary layer of Antarctica (SaizLopez and Boxe, 2008). In contrast, in the Arctic boundary layer the IO radical has proved to be difficult to detect, although recently small quantities were detected downwind of open leads or polynyas (Mahajan et al., 2010) suggesting that open ocean could be an important source of iodine instead of sea ice algae as has been proposed for Antarctica. It seems likely that the greater thickness of Arctic sea ice and its impermeability for almost all of the period (Zhou et al., 2013) inhibits the upwelling of iodine through capillary channels in the ice (Saiz-Lopez and Boxe, 2008), and so atmospheric iodine in the Arctic is instead associated with air flow above ocean surfaces.

Considering that the main atmospheric iodine source is biological primary production in colder waters, the iodide concentration is lower (R. Chance, University of York, personal communication, 2013) and so the production of HOI and $I_{2}$ from the uptake of $\mathrm{O}_{3}$ at the ocean surface is less significant, the primary biological bloom occurs around Svalbard during the March-May period (Ardyna et al., 2013), and that iodine is primarily emitted from the open-ocean surface, we can now evaluate the change in sea ice extension around Svalbard during the period covered by the firn core. The iodine profiles from Svalbard show two periods with high concentrations: between 2004-2006 and 2011-2012 where concentrations exceeded $50 \mathrm{pg} \mathrm{g}^{-1}$ (Fig. 3). These higher concentrations can be associated with a decrease in the March-May sea ice extension (Fig. 3). In this first evaluation we use the total Arctic sea ice extension; however, a more detailed evaluation is necessary to better understand which Arctic sectors (Fig. 1b) are most likely to influence the observed iodine deposition at Svalbard.

Accurate estimation of the sea ice areas influencing iodine deposition to Svalbard is difficult due to the variability of many factors such as air mass direction and speed, exchange with the free troposphere, and deposition of iodine compounds en route to the sampling site. The partitioning of iodine species between aerosol gas phase is a further uncertainty (Saiz-Lopez et al., 2012). Average March-May three-day back trajectories for the period 2003-2011 from the Holtedahlfonna drilling site (Fig. 4), together with previous studies (Rozwadowska et al., 2010; Eleftheriadis et al., 2009), suggest that air masses predominantly originate from the Greenland, Barents and Kara seas and the Arctic Basin. However considering the atmospheric lifetime of some organic compounds $\left(\mathrm{CH}_{3} \mathrm{I}\right)$ are on the order of 2-6 days (Carpenter, 2003), we extend our back trajectory calculation to 6 days. These results confirm the influence of the above mentioned basins but also indicate a possible influence of Baffin Bay. Back trajectory calculations suggest that the Greenland sea, Barents sea and Baffin Bay regions could be considered the most important source regions for iodine. In particular, excluding the Okhotsk and Bering sea, the change in March-May sea ice in these basins can explain the total Arctic sea ice change during the March-May period. However, if we consider the change for a single basin only a poor link with iodine is detected (Fig. 5e, f, g). Instead when we consider the sum of these three basins the retreat in March-May (Fig. 5i) sea ice is well mirrored by iodine concentrations in the core. These interpretations are partially confirmed by preliminary statistical results. A negative significant correlation is found between Iodine and Baffin $(r=-0.70$, $p$ value $=0.019$, adj. $p=0.033)$ and between Iodine and Greenland sea $(r=-0.63, p$ value $=0.034$, adj. $p=0.033)$, but no significant correlation is found between Iodine and Barents sea $(r=-0.32, p$ value $=0.204$, adj. $p=0.204)$. A statistically significant negative correlation $(r=-0.64, p$ value $=0.031$, adj. $p=0.038$ ) is found when considering the retreat in March-May sea ice of the three basins combined. However, Kendall tau rank correlation is doubtful about the presence of a significant negative association between Iodine and the three combined basins $(\tau=-0.5, p$ value $=0.038$, adj. $p=0.113$ ). Given the discrepancy between Pearson correlation and Kendal tau, the significance of the correlation results are to be considered indicative and preliminary. The 

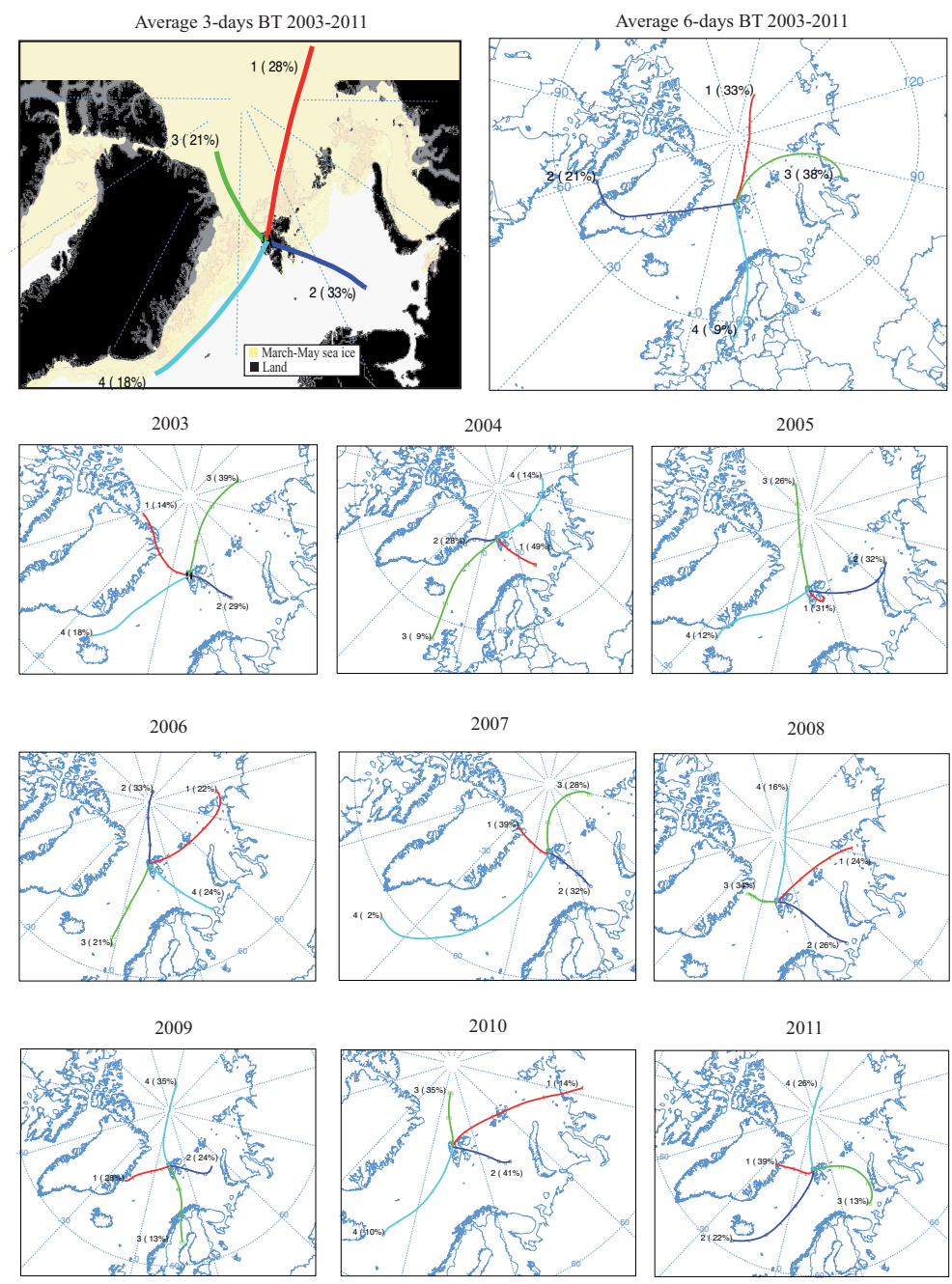

Fig. 4. March-May back trajectory (BT) calculations using HYSPLIT during the period 2003-2011. Average 3 and 6 day back trajectories are shown in the first top chart. Three-day back trajectory calculations for each year are also shown.

negative correlation suggests that the cover of March-May sea ice influences the iodine flux. If iodine was emitted in substantial quantities by algae blooming under the sea ice, a positive association between sea ice extension and I concentration should have been observed. Such an interpretation is supported by differential optical absorption spectroscopy (DOAS) measurements of atmospheric iodine in the Canadian Arctic that show that IO concentrations become detectable only in the presence of open sea water (Mahajan et al., 2010). No significant IO signal was recorded when air masses flowed above solid sea ice (Mahajan et al., 2010), implying that percolation of I through the sea ice may not be a major IO emission mechanism in the Arctic.

Sturges and Barrie (1988) determined iodine and bromine concentrations in Canadian Arctic aerosol, demonstrating that I fluxes increased sharply during the March-May period. This behaviour is likely associated with the phytoplank- ton bloom that occurs with the dawn of solar radiation in the March-May period. The variation in biological primary productivity has also been investigated in relation to the presence of open-ocean water in the Arctic (Pabi et al., 2008; Anderson and Kaltin, 2001). However, the reaction of deposited $\mathrm{O}_{3}$ with $\mathrm{I}^{-}$at the exposed ocean surface may also make a significant contribution during summer and fall.

Despite aerosol studies demonstrating the seasonality of the iodine deposition in Canadian Arctic with maximum deposition in the March-May period (Sturges and Barrie, 1988), seasonal fluctuations of Iodine were not clearly visible in the firn core profile (Fig. 3). The absence of seasonality in the iodine signal could be due to smoothing of the signal resulting from meltwater percolation at the site. It has been shown that acidic species, such as nitrate and sulfate, can be disturbed by surface melting and meltwater percolation in Svalbard snow despite the preservation of the $\delta^{18} \mathrm{O}$ 

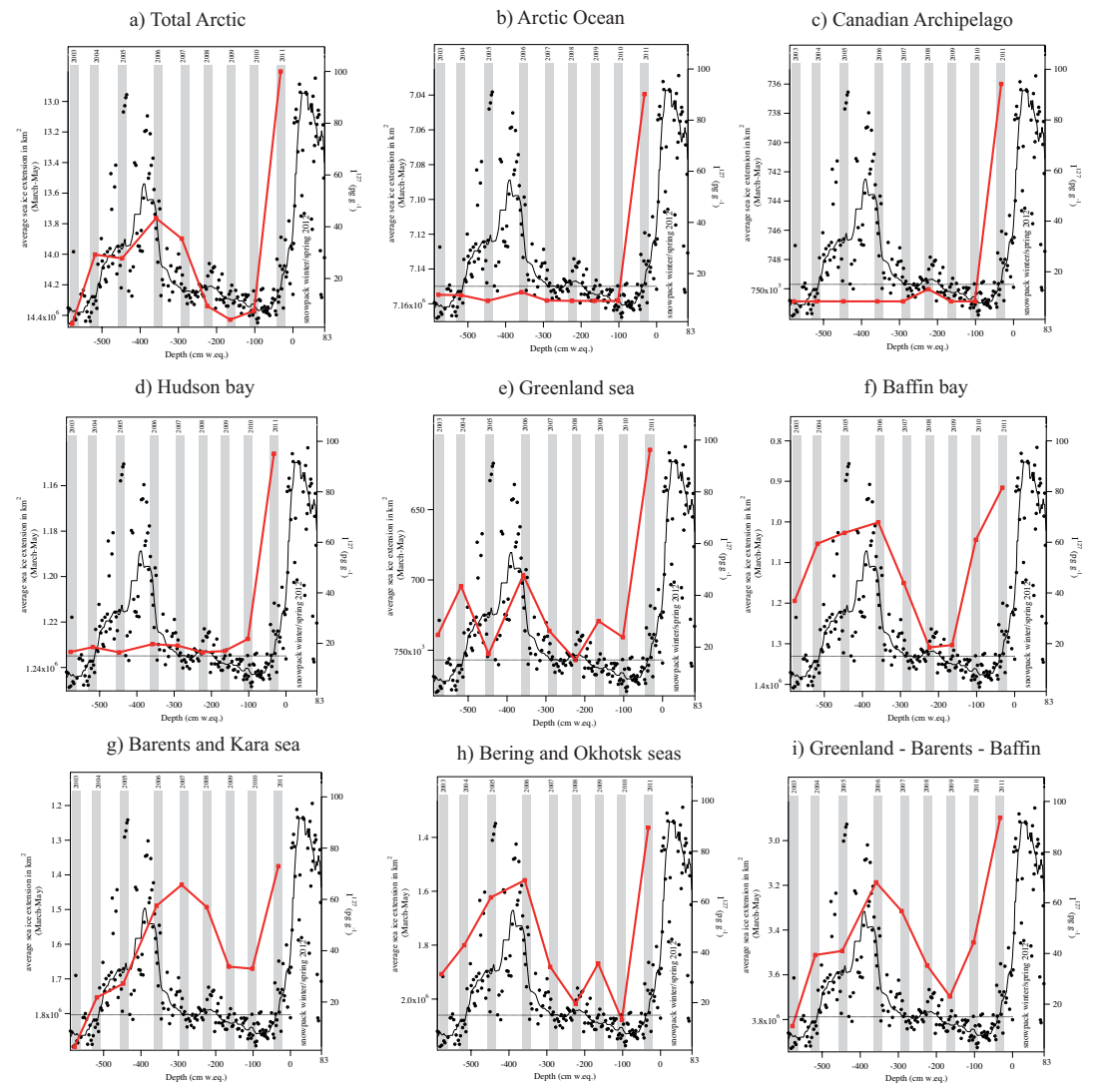

Fig. 5. Comparison of Iodine trend in the firn core recovered with changes in March-May sea ice from single sectors. Panel (g) shows the sum of the Greenland sea, Barents sea and Baffin bay regions.

signal as well as those of other less-reactive species (Pohjola et al., 2002). In such a case, Iodine concentrations will not show an annual cycle but could still be indicative of mean annual Iodine deposition. Though our data suggest a linkage between March-May sea ice retreat and iodine emission we need to consider the relationship between these two parameters. The iodine signal suggests that changes in the Barents, Kara and Greenland seas and Baffin Bay are likely to be the main sources for Iodine deposited in Svalbard. However we need to consider that the observed $30-50 \%$ change of March-May sea ice in these regions results in a tenfold change in the iodine signal. In the Arctic it appears likely that non-linear processes are involved in the emission, transport and/or deposition of iodine. This may be due to non-linear biological responses to ocean water coverage, or the additional influence of other factors such as nutrient availability. An alternative could be that the iodine observed at Svalbard actually originates from quite small and specific regions of open water that are being expanded by a much larger factor, but whose area is related to the general retreat of the ice. It is not possible to speculate further on such non-linear responses to sea ice change until Iodine emission sources are better known.

\subsection{Bromine enrichment and seasonal sea ice}

Bromine concentrations in Holtedahlfonna glacier samples ranged from 0.43 to $7.36 \mathrm{ng} \mathrm{g}^{-1}$. As with $\mathrm{Na}$, sea water is the primary emission source of atmospheric Br. Although the total $\mathrm{Br}$ concentration has a statistically significant positive association with $\mathrm{Na}(r=0.78, p$ value $<0.001)$, $\mathrm{Br}$ could have an additional atmospheric production source which must be accounted for. $\mathrm{Br}_{2}$ is produced by the uptake of $\mathrm{HOBr}$ on brine and snow covered (including frost flowers) first year sea ice. Photolysis of $\mathrm{Br}_{2}$ then produces $\mathrm{Br}$ atoms which react with $\mathrm{HO}_{2}$ radicals to reform $\mathrm{HOBr}$, thus setting up an efficient auto-catalytic cycle known as a bromine explosion (Pratt et al., 2013). Once in the gas phase, the major sink for bromine is $\mathrm{HBr}$, formed by the reaction of $\mathrm{Br}$ atoms with $\mathrm{HCHO}$. $\mathrm{HBr}$ can then be deposited as bromide ions in the snowpack. In order to evaluate the sensitivity of $\mathrm{Br}$ as a tracer of sea ice extension, it is necessary to remove the sea spray component by applying a correction based on the $\mathrm{Br} / \mathrm{Na}$ mass ratio in sea water. We used a $\mathrm{Br} / \mathrm{Na}$ mass ratio value of 0.006 (Millero, 1974). The bromine enrichment percentage $\left(\% \mathrm{Br}_{\text {enr }}\right)$ was calculated using the formula $\left(\left(\left[\mathrm{Br}_{\text {ice }}\right] /\left(\left[\mathrm{Na}_{\text {ice }}\right] \times 0.006\right) \times 100\right)-100\right)$, where a value of $\% \mathrm{Br}_{\text {enr }}$ equal to zero indicates an absence of $\mathrm{Br}$ enrichment 


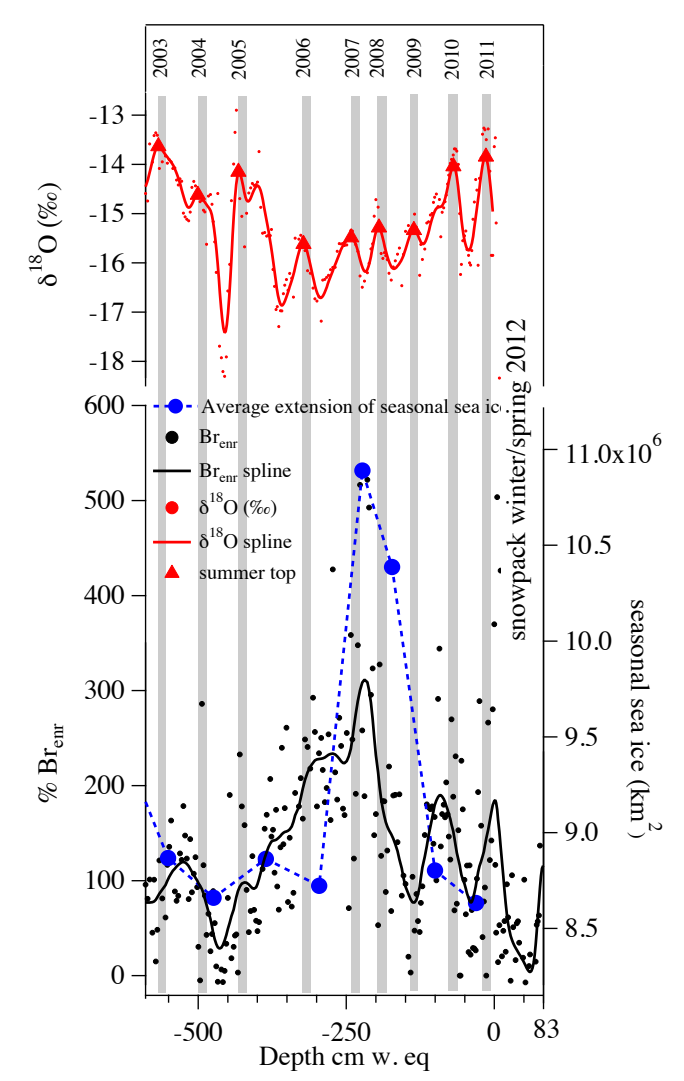

Fig. 6. Bromine enrichment ( $\% \mathrm{Br}_{\mathrm{enr}}$, black circles) is compared to seasonal sea ice area (blue circles). Seasonal sea ice area was calculated as the difference between the March maxima of sea ice and the September sea ice minima of the previous year. Seasonal variability of $\% \mathrm{Br}_{\mathrm{enr}}$ is present in the upper part of the core. Bromine is enriched relative to seawater $\mathrm{Na}$ during the springtime, when the seasonal sea ice-produced Bromine explosion is most active. The grey bars indicate summer periods. Sea ice data from NSIDC.

compared to the $\mathrm{Br} / \mathrm{Na}$ mass ratio. Hence, only positive $\% \mathrm{Br}_{\text {enr }}$ values indicate production of $\mathrm{Br}$ as a result of the $\mathrm{Br}$ explosion.

The Holtedahlfonna glacier firn core record indicates that $\mathrm{Br}$ is almost always enriched beyond representative seawater values, in some cases up to 6 times in 2008 (Fig. 6). Only a few samples are slightly depleted below seawater values. We find rather constant $\% \mathrm{Br}_{\mathrm{enr}}$ values of approximately 100 between 2003 and 2005, followed by a steady increase to a maximum of 350 in 2008 and then a return to values of approximately 100 between 2009 and 2012 .

Sturges and Barrie (1988) and Toom-Sauntry et al. (2002) reported higher concentrations of $\mathrm{Br}$ in aerosol from March to May with a maximum in April. The consistent springtime enrichment of $\mathrm{Br}$, beyond concentrations expected from solely marine salt inputs, suggests that the springtime peak of bromine explosion activity is the main source for additional $\mathrm{Br}$ deposited in Svalbard glaciers. Bromine is a partic- ularly active element above seasonal sea ice during springtime. Satellite and field-based observations clearly show the springtime increase of atmospheric $\mathrm{BrO}$ concentrated above first-year sea ice (Nghiem et al., 2012; Pratt et al., 2013). The highest Arctic atmospheric $\mathrm{BrO}$ values are located above the seasonal sea ice and decrease above the older multiyear sea ice toward the seasonal sea ice margin (Richter et al., 1998; Sihler et al., 2012; Theys et al., 2011).

With these findings we compare $\% \mathrm{Br}_{\text {enr }}$ with Arctic seasonal sea ice extension, where seasonal sea ice was calculated by subtracting the September (minimum) sea ice area from the March (maximum) sea ice area of the following year (Cavalieri et al., 1996). As was the case for I, we initially evaluate the $\% \mathrm{Br}_{\text {enr }}$ versus the total Arctic seasonal sea ice extent (Fig. 7a). The results obtained from the Holtedahlfonna glacier firn core show a positive relationship between seasonal sea ice area and $\% \mathrm{Br}_{\text {enr }}$. Both parameters increased after 2005 to a maximum in 2008, followed by lower values from 2009 to 2012 . The similar trends of $\% \mathrm{Br}_{\text {enr }}$ to those of seasonal sea ice area seem to support our interpretation that absolute $\% \mathrm{Br}_{\text {enr }}$ values are consistent with a sea icerelated source of $\mathrm{Br}$ production. Using the total Arctic sea ice extension may not be appropriate, so we have evaluated the change in seasonal sea ice for the various Arctic sectors (Fig. 7) and the path of 3 day back trajectories for individual years and on average during the period 2003-2011 (Fig. 5). Considering the relatively fast deposition velocity of gas phase bromine $(\mathrm{HBr})$, it is likely that the enrichment of bromine is more regionally influenced than for iodine. Back trajectories suggest that two possible sources are the Arctic Ocean and the Canadian Archipelago (Fig. 4). The southward back trajectories seem not to cross sea ice regions however we cannot exclude the influence of the ice-covered areas of the Greenland and Barents seas. In contrast, the influence of the Bering and Okhotsk seas can be considered negligible. We plotted the changes in seasonal sea ice for each region (Fig. 7) with the bromine enrichment and find a good agreement when we consider the changing seasonal sea ice in the Arctic Ocean (Fig. 7b), Canadian Arctic (Fig. 7c) and Hudson Bay (Fig. 7d). While the influence of the Arctic Ocean and Canadian Archipelago seem to also be confirmed by back trajectory calculations, the influence of Hudson Bay $\mathrm{Br}$ sources seems unlikely. The poor agreement between the $\% \mathrm{Br}_{\text {enr }}$ and seasonal sea ice in the Greenland and Barents seas suggest a negligible role also for these sea ice regions.

In parallel with these qualitative interpretations we also calculated statistical correlations. As for iodine, due to the short data series, we need to consider these results indicative and preliminary. However, the statistical analysis suggests a positive correlation with Arctic Ocean $(r=0.81, p$ value $=0.008$, adj. $p=0.036$ ) and Canadian Archipelago $(r=0.92, p$ value $=0.001$, adj. $p=0.006)$. Kendall tau suggests a somehow weaker significance for both Arctic Ocean $($ tau $=0.71, p$ value $=0.007$, adj. $p=0.064)$ and Canadian Archipelago $($ tau $=0.64, p$ value $=0.016$, adj. $p=0.070)$. 


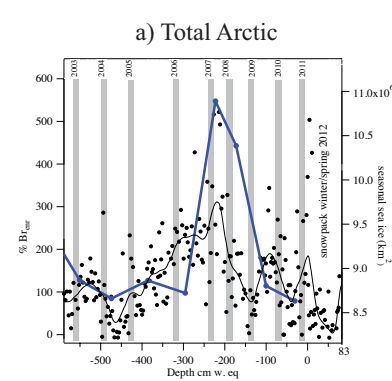

d) Hudson Bay

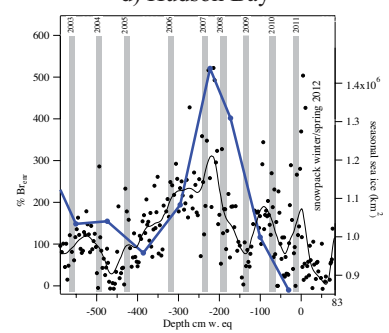

g) Barents and Kara Seas

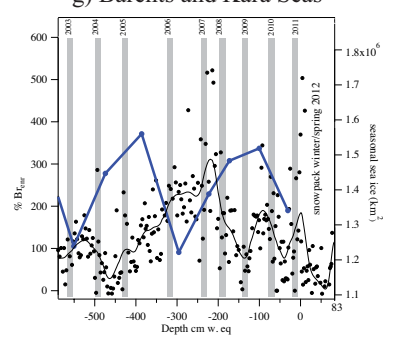

b) Arctic ocean

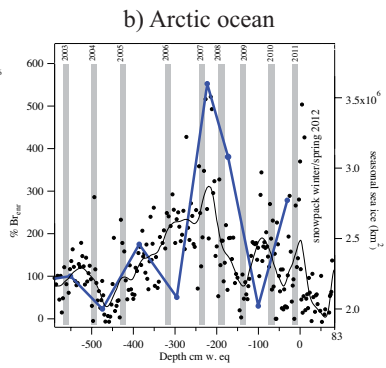

e) Greenland Sea

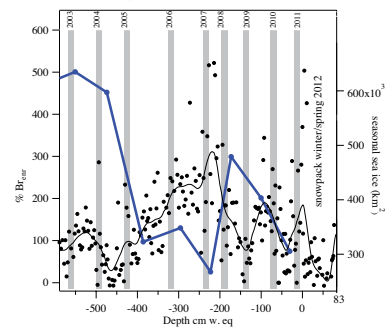

h) Bering Sea

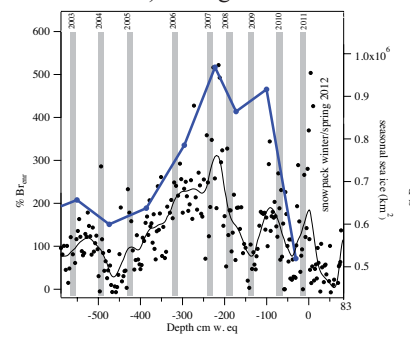

c) Canadian Archipelago

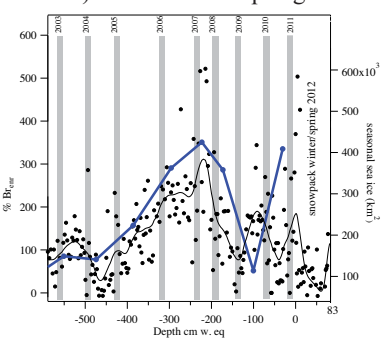

f) Baffin Bay
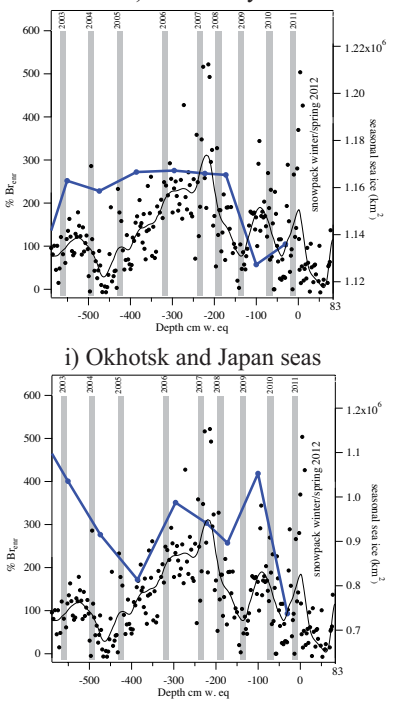

Fig. 7. Comparison of $\% \mathrm{Br}_{\mathrm{enr}}$ trend in the firn core recovered with changes in seasonal sea ice from single Arctic sectors.

The change in Arctic Ocean seasonal sea ice is in good agreement with the change in $\% \mathrm{Br}_{\text {enr }}$ with both showing maxima between 2008 and 2009. However in 2007 there is some disagreement with a decrease in Arctic Ocean seasonal sea ice and an increase of $\% \mathrm{Br}_{\text {enr }}$. The March-May back trajectories of 2007 show an enhanced influence of the sea ice region at the north of Greenland. It is therefore possible that during 2007 an increase in the influence of Canadian Archipelago sea ice could have had more effect on $\% \mathrm{Br}_{\text {enr }}$.

Though we suggest that the main driver of bromine enrichment found in the shallow firn core are chemical reactions connected to seasonal sea ice, the role of biological $\mathrm{Br}$ emissions was also evaluated. If biological emissions were to play an important role then a positive correlation would be expected between I and $\% \mathrm{Br}_{\text {enr. }}$. In the data presented here, these two parameters show a statistically significant negative association of -0.32 ( $p$ value $<0.001$ ) suggesting that their fluxes are controlled by opposing sources and/or processes. We suggest that a decrease in seasonal sea ice area causes a decrease in the area available to support the Br explosion. Simultaneously, decreased seasonal sea ice contributes to a reduced March-May sea ice extent and hence increased I emission from the open water surface of the Arctic region.
We consider also the post-depositional processes affecting the $\mathrm{Br}$ concentration in the surface snowpack. For instance, the uptake of species such as $\mathrm{HOBr}$ and $\mathrm{HOI}$ in the snowpack could recycle bromide ions to the gas phase as $\mathrm{Br}_{2}$ and $\mathrm{IBr}$, respectively.

Pratt et al. (2013) suggest that two parameters, $\mathrm{pH}$ and the $\mathrm{Br}^{-} / \mathrm{Cl}$ molar ratio, could be used to identify potential bromine emission. Though we do not measure $\mathrm{Cl}$, this can be calculated from sodium concentrations using their abundances in sea water (Krnavek et al., 2012; Bigler et al., 2006). The first $5 \mathrm{~cm}$ present a pH of 4.9 and a $\mathrm{Br}^{-} / \mathrm{Cl}$ ratio of $1 / 57$ suggesting the possibility of bromine re-emission. All the other samples present greater $\mathrm{pH}$ values, with an average of 5.3 and an average $\mathrm{Br}^{-} / \mathrm{Cl}$ ratio of $1 / 333$. It is possible that some re-emission of bromine could occur on the fresh snow surface, as suggested by Pratt et al. (2013), however the snow just below $5 \mathrm{~cm}$ does not present favourable conditions for gas-phase bromine release. If recycling processes were significant, then $\% \mathrm{Br}_{\text {enr }}$ would be negative, representing an overall depletion of $\mathrm{Br}$ relative to the marine sea salt value. Percolation, as discussed for iodine, is another process that could disturb the signal. Detecting the seasonal variation in the ${ }^{18} \mathrm{O}$ signal is not a guarantee that all other species have been preserved reliably, as reported by Pohjola 
et al. (2002). $\delta^{18} \mathrm{O}$ exhibits less susceptibility to changes induced by melt-water percolation, compared to soluble and/or volatile acid species. Ionic compounds suffer partly from melt-water percolation but are still able to preserve their atmospheric signal with annual resolution. The loss of seasonality below $150 \mathrm{~cm}$ w.eq. in our $\% \mathrm{Br}_{\mathrm{enr}}$ could be explained by the smoothing effect of percolation due to the warmer period between 2007 and 2009 with an enhance of the number of summer positive air temperature (Bednorz and Kolendowicz, 2013). In upper part of the firn core we clearly distinguish the seasonality suggesting that bromine explosion events are recorded in the snow deposition as detected by satellite and aerosol measurement. As for iodine it appears more likely that seasonality has been affected, but the annual signal is preserved. The maximum in seasonal sea ice extension during the firn core has been reached in 2008 where we detect the maximum bromine enrichment. We cannot exclude that the $\% \mathrm{Br}_{\text {enr }}$ signal was modified but the data are consistent with observed changes in seasonal sea ice extension. As for iodine we cannot deduce from the data the relationship between change in seasonal sea ice and $\% \mathrm{Br}_{\text {enr }}$. Our results suggest that for a $10 \%$ change in overall sea ice we have a doubling of bromine enrichment. One possibility is that the $\mathrm{Br}$ reaching Svalbard originates from a more specific region whose sea ice area is being changed by a much larger factor. However, we must consider that also the atmospheric transport and the irregular occurrence of bromine explosion events complicate the identification of predictive relationships.

\section{Future development}

Iodine and $\mathrm{Br}$ profiles determined in a Holtedahlfonna glacier firn core demonstrate variability that can be related to changes in March-May sea ice extent and seasonal sea ice area during the past decade. The enrichment of $\mathrm{Br}$ in ice, relative to the sea salt proxy $\mathrm{Na}$, can be attributed to the bromine explosion that occurs above seasonal sea ice during early spring, especially in the regions of the Arctic Ocean and Canadian Archipelago suggesting that the annual variation of $\% \mathrm{Br}_{\text {enr }}$ could be mainly influenced by the variation in the seasonal sea ice extension. Results suggest that the predominant $\mathrm{Br}$ enrichment occurs during spring and early summer; however, the likely percolation effect could have disturbed and smoothed the original signal. While $\mathrm{Br}$ is influenced by the variation of seasonal sea ice area, iodine in Arctic region seems primarily emitted from open water and thus related to the changes in the March-May sea ice extent. In particular, the retreat of March-May sea ice appears to be related to increased I concentrations, resulting from the increased biological productivity associated with open water and the reaction of $\mathrm{O}_{3}$ with iodide ions in the sea surface layer. On the basis of this limited data set, only tentative findings can be reported here. Further studies will be necessary to thoroughly understand and characterize the processes controlling I and
$\mathrm{Br}$ transport and deposition in snow pack. The effect of percolation and possible re-emission after deposition should be investigated, considering the presence of summer melt layers such as those observed in the Holtedahlfonna glacier and the atmospheric reactivity of these two halogens. The data presented here provide a provisional basis for linking $\mathrm{I}$ and $\mathrm{Br}$ to sea ice variability, which could lead eventually to reconstruction of past sea ice variations in the polar regions.

Acknowledgements. This work was supported by the Italian National Research Council (CNR), the Italian Ministry of Research through the PRIN project 2009 and by the EU Regional Development Foundation, project 3.2.0801.12-0044. The authors are rateful to R. Sparapani and E. Liberatori (CNR) for logistical assistance, H. Sevestre and UNIS (The University Centre in Svalbard) for supporting the field operations, and L. Poto (University of Venice) for helpful discussions regarding marine biology.

Edited by: E. Wolff

\section{References}

Aagaard, K. and Carmack, E. C.: The Role of Sea Ice and Other Fresh Water in the Arctic Circulation, J. Geophys. Res., 94, 14485-14498, 1989.

Anderson, L. G. and Kaltin, S.: Carbon fluxes in the Arctic Ocean - potential impact by climate change, Polar Res., 20, 225-232, 2001.

Ardyna, M., Babin, M., Gosselin, M., Devred, E., Bélanger, S., Matsuoka, A., and Tremblay, J.-É.: Parameterization of vertical chlorophyll a in the Arctic Ocean: impact of the subsurface chlorophyll maximum on regional, seasonal, and annual primary production estimates, Biogeosciences, 10, 4383-4404, doi:10.5194/bg-10-4383-2013, 2013.

Atkinson, H. M., Huang, R.-J., Chance, R., Roscoe, H. K., Hughes, C., Davison, B., Schönhardt, A., Mahajan, A. S., Saiz-Lopez, A., Hoffmann, T., and Liss, P. S.: Iodine emissions from the sea ice of the Weddell Sea, Atmos. Chem. Phys., 12, 11229-11244, doi:10.5194/acp-12-11229-2012, 2012.

Bednorz, E. and Kolendowicz, L.: Summer mean daily air temperature extremes in Central Spitsbergen, Theor. Appl. Climatol., 113, 471-479, doi:10.1007/s00704-012-0798-4, 2013.

Benjamini, Y. and Hochberg, Y.: Controlling the False Discovery Rate: A Practical and Powerful Approach to Multiple Testing, J. R. Stat. Soc., Series B (Methodological), 57, 289-300, doi:10.2307/2346101, 1995.

Bigler, M., Röthlisberger, R., Lambert, F., Stocker, T. F., and Wagenbach, D.: Aerosol deposited in East Antarctica over the last glacial cycle: Detailed apportionment of continental and sea-salt contributions, J. Geophys. Res.-Atmos., 111, D08205, doi:10.1029/2005jd006469, 2006.

$\mathrm{Bu}, \mathrm{X}$., Wang, T., and Hall, G.: Determination of halogens in organic compounds by high resolution inductively coupled plasma mass spectrometry (HR-ICP-MS), J. Anal. Atom. Spectrom., 18, 1443-1451, 2003. 
Candelone, J.-P., Hong, S., and Boutron, C.: An improved method for decontaminating polar snow or ice cores for heavy metal analysis, Anal. Chim. Acta., 299, 9-16, 1994.

Carpenter, L. J.: Iodine in the Marine Boundary Layer, Chemical Reviews, 103, 4953-4962, 2003.

Carpenter, L. J., MacDonald, S. M., Shaw, M. D., Kumar, R., Saunders, R. W., Parthipan, R., Wilson, J., and Plane, J. M. C.: Atmospheric iodine levels influenced by sea surface emissions of inorganic iodine, Nature Geosci., 6, 108-111, 2013.

Cavalieri, D. J., Parkinson, C. L., Gloersen, P., and Zwally, A. H.: Sea Ice Concentrations from Nimbus-7 SMMR and DMSP SSM/I-SSMIS Passive Microwave Data, Boulder, Colorado USA: NASA DAAC at the National Snow and Ice Data Center., 1996.

Cronin, T. M., Smith, S. A., Eynaud, F., O'Regan, M., and King, J.: Quaternary paleoceanography of the central Arctic based on Integrated Ocean Drilling Program Arctic Coring Expedition 302 foraminiferal assemblages, Paleoceanography, 23, PA1S18, 2008.

Curran, M. A. J., van Ommen, T. D., Morgan, V. I., Phillips, K. L., and Palmer, A. S.: Ice Core Evidence for Antarctic Sea Ice Decline Since the 1950s, Science, 302, 1203-1206, 2003.

Darby, D. A.: Sources of sediment found in sea ice from the western Arctic Ocean, new insights into processes of entrainment and drift patterns, J. Geophys. Res., 108, 3257, doi:10.1029/2002JC001350, 2003.

Draxler R. R. and Hess, G. D.: An overview of the HYSPLIT 4 modelling system for trajectories, dispersion and deposition, Aust. Meteorol. Mag., 47, 295-308, 1998.

Durner, G. M., Douglas, D. C., Nielson, R. M., Amstrup, S. C., McDonald, T. L., Stirling, I., Mauritzen, M., Born, E. W., Wiig, O., DeWeaver, E., Serreze, M. C., Belikov, S. E., Holland, M. M., Maslanik, J., Aars, J., Bailey, D. A., and Derocher, A. E.: Predicting 21st-century polar bear habitat distribution from global climate models, Ecol. Monogr., 79, 25-58, 2009.

Eleftheriadis, K., Vratolis, S., and Nyeki, S.: Aerosol black carbon in the European Arctic: Measurements at Zeppelin station, Ny-Alesund, Svalbard from 1998-2007, Geophys. Res. Lett., 36, L02809, doi:10.1029/2008GL035741, 2009.

Fahl, K. and Stein, R.: Modern seasonal variability and deglacial/Holocene change of central Arctic Ocean sea-ice cover: New insights from biomarker proxy records, Earth Planet. Sc. Lett., 351, 123-133, 2012.

Fan, S.-M. and Jacob, D. J.: Surface ozone depletion in Arctic spring sustained by bromine reactions on aerosols, Nature, 359, 522-524, 1992.

Francis, J. A., Chan, W., Leathers, D. J., Miller, J. R., and Veron, D. E.: Winter Northern Hemisphere weather patterns remember summer Arctic sea-ice extent, Geophys. Res. Lett., 36, L07503, doi:10.1029/2009GL037274, 2009.

Gabrielli, P., Planchon, F. A. M., Hong, S., Lee, K. H., Hur, S. D., Barbante, C., Ferrari, C. P., Petit, J. R., Lipenkov, V. Y., Cescon, P., and Boutron, C. F.: Trace elements in Vostok Antarctic ice during the last four climatic cycles, Earth Planet. Sc. Lett., 234, 249-259, 2005

Holland, M. M., Bitz, C. M., Eby, M., and Weaver, A. J.: The Role of Ice-Ocean Interactions in the Variability of the North Atlantic Thermohaline Circulation, J. Climate, 14, 656-675, 2001.
Ibanez, F., Grosjean, P., and Etienne, M.: Pastecs: Package for Analysis of Space-Time Ecological Series, R package version, 1, 3$11,2009$.

Isaksson, E., Kekonen, T., Moore, J., and Mulvaney, R.: The methanesulfonic acid (MSA) record in a Svalbard ice core, Ann. Glaciol., 42, 345-351, 2005.

Kaleschke, L., Richter, A., Burrows, J., Afe, O., Heygster, G., Notholt, J., Rankin, A., Roscoe, H., Hollwedel, J., and Wagner, T.: Frost flowers on sea ice as a source of sea salt and their influence on tropospheric halogen chemistry, Geophys. Res. Lett., 31, L16114, doi:10.1029/2004GL020655, 2004.

Kalnay, E., Kanamitsu, M., Kistler, R., Collins, W., Deaven, D., Gandin, L., Iredell, M., Saha, S., White, G., Woollen, J., Zhu, Y., Leetmaa, A., Reynolds, R., Chelliah, M., Ebisuzaki, W., Higgins, W., Janowiak, J., Mo, K. C., Ropelewski, C., Wang, J., Jenne, R., and Joseph, D.: The NCEP/NCAR 40-Year Reanalysis Project, B. Am. Meteorol. Soc., 77, 437-471, doi:10.1175/15200477(1996)077<0437:tnyrp>2.0.co;2, 1996.

Kendall, M. G.: Time-serie, 2nd ed., Charles Griffin \& Co, London, 1976.

Kinnard, C., Zdanowicz, C. M., Fisher, D. A., Isaksson, E., de Vernal, A., and Thompson, L. G.: Reconstructed changes in Arctic sea ice over the past 1,450 years, Nature, 479, 509-512, 2011.

Krnavek, L., Simpson, W. R., Carlson, D., Domine, F., Douglas, T. A., and Sturm, M.: The chemical composition of surface snow in the Arctic: Examining marine, terrestrial, and atmospheric influences, Atmos. Environ., 50, 349-359, doi:10.1016/j.atmosenv.2011.11.033, 2012.

Lisitzin, A. P.: Sea-ice and Iceberg Sedimentation in the Ocean: Recent and Past, edited by: Springer-Verlag, Berlin, Heidelberg, 2002.

Mahajan, A. S., Shaw, M., Oetjen, H., Hornsby, K. E., Carpenter, L. J., Kaleschke, L., Tian-Kunze, X., Lee, J. D., Moller, S. J., Edwards, P., Commane, R., Ingham, T., Heard, D. E., and Plane, J. M. C.: Evidence of reactive iodine chemistry in the Arctic boundary layer, J. Geophys. Res., 115, D20303, doi:10.1029/2009JD013665, 2010.

Millero, F. J.: The Physical Chemistry of Seawater, Annu. Rev. Earth Planet. Sci., 2, 101-150, doi:10.1146/annurev.ea.02.050174.000533, 1974.

Nghiem, S. V., Rigor, I. G., Richter, A., Burrows, J. P., Shepson, P. B., Bottenheim, J., Barber, D. G., Steffen, A., Latonas, J., Wang, F., Stern, G., Clemente-Colòn, P., Martin, S., Hall, D. K., Kaleschke, L., Tackett, P., Neumann, G., and Asplin, M. G.: Field and satellite observations of the formation and distribution of Arctic atmospheric bromine above a rejuvenated sea ice cover, J. Geophys. Res., 117, D00S05, doi:10.1029/2011JD016268, 2012.

O’Dwyer, J., Isaksson, E., Vinje, T., Jauhiainen, T., Moore, J., Pohjola, V., Vaikmäe, R., and van de Wal, R. S. W.: Methanesulfonic acid in a Svalbard Ice Core as an indicator of ocean climate, Geophys. Res. Lett., 27, 1159-1162, 2000.

Pabi, S., van Dijken, G. L., and Arrigo, K. R.: Primary production in the Arctic Ocean, 1998-2006, J. Geophys. Res., 113, C08005, doi:10.1029/2007JC004578, 2008.

Parkinson, C. L. and Comiso, J. C.: On the 2012 record low Arctic sea ice cover: Combined impact of preconditioning and an August storm, Geophys. Res. Lett., 40, 1356-1361, doi:10.1002/grl.50349, 2013. 
Petit, J. R., Jouzel, J., Raynaud, D., Barkov, N. I., Barnola, J. M., Basile, I., Bender, M., Chappellaz, J., Davis, M., Delaygue, G., Delmotte, M., Kotlyakov, V. M., Legrand, M., Lipenkov, V. Y., Lorius, C., Pepin, L., Ritz, C., Saltzman, E., and Stievenard, M.: Climate and atmospheric history of the past 420,000 years from the Vostok ice core, Antarctica, Nature, 399, 429-436, 1999.

Pohjola, V. A., Moore, J. C., Isaksson, E., Jauhiainen, T., van de Wal, R. S. W., Martma, T., Meijer, H. A. J., and Vaikmäe, R.: Effect of periodic melting on geochemical and isotopic signals in an ice core from Lomonosovfonna, Svalbard, J. Geophys. Res.Atmos., 107, 1-14, 2002.

Polyak, L., Alley, R. B., Andrews, J. T., Brigham-Grette, J., Cronin, T. M., Darby, D. A., Dyke, A. S., Fitzpatrick, J. J., Funder, S., Holland, M., Jennings, A. E., Miller, G. H., O’Regan, M., Savelle, J., Serreze, M., St. John, K., White, J. W. C., and Wolff, E.: History of sea ice in the Arctic, Quaternary Sci. Rev., 29, 1757-1778, 2010.

Pratt, K. A., Custard, K. D., Shepson, P. B., Douglas, T. A., Pohler, D., General, S., Zielcke, J., Simpson, W. R., Platt, U., Tanner, D. J., Gregory Huey, L., Carlsen, M., and Stirm, B. H.: Photochemical production of molecular bromine in Arctic surface snowpacks, Nature Geosci., 6, 351-356, doi:10.1038/ngeo1779, 2013.

$\mathrm{R}$ Core Team: $\mathrm{R}$ - A language and environment for statistical computing, R Foundation for Statistical, Vienna, 2011.

Rampal, P., Weiss, J., Dubois, C., and Campin, J. M.: IPCC climate models do not capture Arctic sea ice drift acceleration: Consequences in terms of projected sea ice thinning and decline, J. Geophys. Res., 116, C00D07, doi:10.1029/2011JC007110, 2011.

Rankin, A. M., Auld, V., and Wolff, E. W.: Frost flowers as a source of fractionated sea salt aerosol in the polar regions, Geophys. Res. Lett., 27, 3469-3472, 2000.

Richter, A., Wittrock, F., Eisinger, M., and Burrows, J. P.: GOME observations of tropospheric $\mathrm{BrO}$ in northern hemispheric spring and summer 1997, Geophys. Res. Lett., 25, 2683-2686, 1998.

Roscoe, H. K., Brooks, B., Jackson, A. V., Smith, M. H., Walker, S. J., Obbard, R. W., and Wolff, E. W.: Frost flowers in the laboratory: Growth, characteristics, aerosol, and the underlying sea ice, J. Geophys. Res.-Atmos., 116, D12301, doi:10.1029/2010jd015144, 2011.

Rozwadowska, A., Zielin'ski, T., Petelski, T., and Sobolewski, P.: Cluster analysis of the impact of air back-trajectories on aerosol optical properties at Hornsund, Spitsbergen, Atmos. Chem. Phys., 10, 877-893, doi:10.5194/acp-10-877-2010, 2010.

Saiz-Lopez, A. and Boxe, C. S.: A mechanism for biologicallyinduced iodine emissions from sea-ice, Atmos. Chem. Phys. Discuss., 8, 2953-2976, doi:10.5194/acpd-8-2953-2008, 2008.

Saiz-Lopez, A. and Plane, J.: Novel iodine chemistry in the marine boundary layer, Geophys. Res. Lett., 31, L04112, doi:10.1029/2003GL019215, 2004.

Saiz-Lopez, A., Chance, K., Liu, X., Kurosu, T. P., and Sander, S. P.: First observations of iodine oxide from space, Geophys. Res. Lett., 34, L12812, doi:10.1029/2007GL030111, 2007.

Saiz-Lopez, A., Plane, J. M. C., Baker, A. R., Carpenter, L. J., von Glasow, R., Gomez Martin, J. C., McFiggans, G., and Saunders, R. W.: Atmospheric Chemistry of Iodine, Chem. Rev., 112, 1773-1804, 2012.
Schönhardt, A., Richter, A., Wittrock, F., Kirk, H., Oetjen, H., Roscoe, H. K., and Burrows, J. P.: Observations of iodine monoxide columns from satellite, Atmos. Chem. Phys., 8, 637-653, doi:10.5194/acp-8-637-2008, 2008.

Schönhardt, A., Begoin, M., Richter, A., Wittrock, F., Kaleschke, L., Gómez Martín, J. C., and Burrows, J. P.: Simultaneous satellite observations of IO and BrO over Antarctica, Atmos. Chem. Phys., 12, 6565-6580, doi:10.5194/acp-12-6565-2012, 2012.

Serreze, M. C., Maslanik, J. A., Scambos, T. A., Fetterer, F., Stroeve, J., Knowles, K., Fowler, C., Drobot, S., Barry, R. G., and Haran, T. M.: A record minimum arctic sea ice extent and area in 2002, Geophys. Res. Lett., 30, 1110, doi:10.1029/2002gl016406, 2003.

Sihler, H., Platt, U., Beirle, S., Marbach, T., Kühl, S., Dörner, S., Verschaeve, J., Frieß, U., Pöhler, D., Vogel, L., Sander, R., and Wagner, T.: Tropospheric BrO column densities in the Arctic derived from satellite: retrieval and comparison to ground-based measurements, Atmos. Meas. Tech., 5, 27792807, doi:10.5194/amt-5-2779-2012, 2012.

Simpson, W. R., Carlson, D., Hönninger, G., Douglas, T. A., Sturm, M., Perovich, D., and Platt, U.: First-year sea-ice contact predicts bromine monoxide (BrO) levels at Barrow, Alaska better than potential frost flower contact, Atmos. Chem. Phys., 7, 621-627, doi:10.5194/acp-7-621-2007, 2007.

Smith, B. T., Van Ommen, T. D., and Curran, M. A. J.: Methanesulphonic acid movement in solid ice cores, Ann. Glaciol., 39, 540-544, doi:10.3189/172756404781814645, 2004.

Stern, H. L., Rothrock, D. A., and Kwok, R.: Open water production in Arctic sea ice: Satellite measurements and model parameterizations, J. Geophys. Res., 100, 20601-20612, 1995.

Stroeve, J., Holland, M. M., Meier, W., Scambos, T., and Serreze, M.: Arctic sea ice decline: Faster than forecast, Geophys. Res. Lett., 34, L09501, doi:10.1029/2007GL029703, 2007.

Sturges, W. T. and Barrie, L. A.: Chlorine, Bromine and Iodine in arctic aerosols, Atmos. Environ., 22, 1179-1194, 1988.

Theys, N., Van Roozendael, M., Hendrick, F., Yang, X., De Smedt, I., Richter, A., Begoin, M., Errera, Q., Johnston, P. V., Kreher, K., and De Mazière, M.: Global observations of tropospheric BrO columns using GOME-2 satellite data, Atmos. Chem. Phys., 11, 1791-1811, doi:10.5194/acp-11-1791-2011, 2011.

Toom-Sauntry, D. and Barrie, L. A.: Chemical composition of snowfall in the high Arctic: 1990-1994, Atmos. Environ., 36, 2683-2693, doi:10.1016/S1352-2310(02)00115-2, 2002.

Turekian, K. K.: Oceans, Prentice-Hall, 1968.

Vare, L. L., Massé, G., Gregory, T. R., Smart, C. W., and Belt, S. T.: Sea ice variations in the central Canadian Arctic Archipelago during the Holocene, Quaternary Sci. Rev., 28, 1354-1366, 2009.

Wang, M. and Overland, J. E.: A sea ice free summer Arctic within 30 years: An update from CMIP5 models, Geophys. Res. Lett., 39, L18501, doi:10.1029/2012GL052868, 2012.

Warren, B. A.: Why is no deep water formed in the North Pacific?, J. Mar. Res., 41, 327-347, 1983.

Wolff, E., Fischer, H., Fundel, F., Ruth, U., Twarloh, B., Littot, G. C., Mulvaney, R., Rothlisberger, R., de Angelis, M., Boutron, C. F., Hansson, M., Jonsell, U., Hutterli, M. A., Lambert, F., Kaufmann, P., Stauffer, B., Stocker, T. F., Steffensen, J. P., Bigler, M., Siggaard-Andersen, M. L., Udisti, R., Becagli, S., Castellano, E., Severi, M., Wagenbach, D., Barbante, C., Gabrielli, P., and Gas- 
pari, V.: Southern Ocean sea-ice extent, productivity and iron flux over the past eight glacial cycles, Nature, 440, 491-496, 2006.

Wolff, E., Barbante, C., Becagli, S., Bigler, M., Boutron, C., Castellano, E., De Angelis, M., Federer, U., Fischer, H., and Fundel, F.: Changes in environment over the last 800,000 years from chemical analysis of the EPICA Dome C ice core, Quaternary Sci. Rev., 29, 285-295, 2010.
Zhou, J., Delille, B., Eicken, H., Vancoppenolle, M., Brabant, F., Carnat, G., Geilfus, N.-X., Papakyriakou, T., Heinesch, B., and Tison, J.-L.: Physical and biogeochemical properties in landfast sea ice (Barrow, Alaska): Insights on brine and gas dynamics across seasons, J. Geophys. Res.-Oceans, 118, 3172-3189, doi:10.1002/jgrc.20232, 2013. 